\title{
A Conceptual Study of Marketing Strategy and Development of SME
}

\author{
Sathana $\mathbf{V}^{*}$, Velnampy T and Rajumesh S
}

Department of Marketing, Faculty of Management Studies and Commerce, University of Jaffna, Jaffna, Sri Lanka

\begin{abstract}
The purpose of this research is to reveal a framework of marketing strategy and development of SMEs in the postwar market. This paper discusses the deepest and new insights of marketing strategies and the development of SMEs. Pilot study revealed that SMEs in postwar market contains huge marketing problems, there is a need to develop the unique frame work of marketing strategies to face dynamic, competitive world and postwar environment. Based on the theories and model of marketing strategies and development, novelty framework was discovered for the postwar market. The recommended five dimensions of marketing strategies are competitive marketing strategy, relationship marketing strategy, social marketing strategy, related diversification and green marketing strategy. In addition the five types of development were developed as financial, customer, employees, growth and social perspectives. This study has practical implication with suggesting major strategies for development of SMEs in the postwar market; these strategies are also roadmap to foothold the nation towards the emerging market. This conceptualized framework model revealed very practical, realistic and applicable insights of marketing strategies for postwar SMEs, instead of recommending any common strategies for organizations. Further this marketing strategic framework will suggest means to achieve competitive advantage and the development of the SMEs.
\end{abstract}

Keywords: Marketing strategy; Development of SMEs; Post war environment

\section{Introduction}

SME sector was seriously affected by nearly three decades of separatist war between 1983 and 2009 in Sri Lanka and post war environment contains destruction of infrastructure, poverty, regional imbalance, low income, poor education, psychological effects on society and women headed families. While war affected entire Sri Lanka, the Northern Province suffered the worst damage. Frontier market countries possess small market capitalizations, low annual turnover, market restrictions, inadequate infrastructure, instable government systems, extreme economic and political instability, weak human capital, and poor with economic growth. Sri Lanka is categorized under the frontier market by FTSE in 2014. Both combination of post war and frontier market condition with competitive, global, environmental and technological challenges creates a critical marketing situation for entrepreneurs in Northern Province (NP). SMEs in NP have captured 99\% of enterprises, at the same time low and fluctuating gross domestic product (GDP) contribution of NP which displays poor performance of SMEs. Marketing of goods or services is the ultimate objectives and goals of organizations for all types of organizations. Application of proper marketing strategies catches up the sustainable growth of organizations. Marketing strategy is a marketing logic and leads to achievement of marketing objectives of business units [1]. Target market explains the area of opportunities [2], marketing strategy speaks about the target market and its marketing mix [3,4]. Effective marketing strategies reflect a rigorous understanding of competition and display greater sensitivity to the competitive nature of the market-place. The SME sector has been identified as an important strategic sector in the overall policy objectives of the Government of Sri Lanka (GOSL) and it is seen as a driver of change for inclusive economic growth, regional development, employment generation and poverty reduction [5]. Marketing strategy contributes for the developments of organization. Intelligent firms develop their business by applying proper marketing strategies, but impoverished firms fail to do so [6]. Therefore this paper aims to develop conceptual model of proper marketing strategies and the development of SMEs in Northern Province in postwar market.

\section{SMEs in Postwar Market}

SMEs play prominent role in any economy through employments generation, GDP contribution, embarking innovations and stimulation of other economic activities. In Sri Lanka, $80 \%$ of businesses are SMEs business and 35\% employment opportunity [7] is offered by the SMEs in 2012. In Sri Lanka the micro establishments are around $92 \%$ and generate employments only for $45 \%$ [8]. SME sector is envisaged to contribute to transform lagging regions into emerging regions of prosperity [9]. In the Northern Province 99\% (micro 92.9\%, small $6.4 \%$, medium $0.6 \%$ ) of business are under the SMEs sector [8].

The three types of global marketplace are developed, emerging, and frontier market. Frontier market is a pre-emerging market; its economic characteristics are young and increasing educated populations. These countries are in the earliest stage of development, growth can be explosive, and the profit potential is enormous, but ethnic unrest creates social risk and hard to reach customers, boycotts and strikes that interrupt the supply chain, getting good information can be difficult and it has lower capitalization and liquidity so the risk is too high. These markets have exciting potential and are worth considering if you can handle the risk [10]. After the 16 year civil war in Sri Lanka, in 2015 government had critical infrastructure projects, including road networks and electricity, further seven years after the end of a devastating civil war, fast development in infrastructure, free market opportunities and global linkages. In contrast Sri Lanka's Northern Province possesses the unsustainable strategy, young unemployment, poverty, low income [11]. Pilot study was made

*Corresponding author: Sathana V, Department of Marketing, Faculty of Management Studies and Commerce, University of Jaffna, Jaffna, Sri Lanka, Tel: +94-718474583; E-mail: Sathana1976@gmail.com

Received June 06, 2018; Accepted July 02, 2018; Published July 10, 2018

Citation: Sathana V, Velnampy T, Rajumesh S (2018) A Conceptual Study of Marketing Strategy and Development of SME. J Account Mark 7: 282. doi: 10.4172/2168-9601.1000282

Copyright: @ 2018 Sathana V, et al. This is an open-access article distributed under the terms of the Creative Commons Attribution License, which permits unrestricted use, distribution, and reproduction in any medium, provided the original author and source are credited. 
to identify the problems of 60 SMEs including 16 SMEs from Jaffna district, 14 from Killinochchi, 18 from Mullaitivu and 12 from Mannar in Northern Province. The answer from owner of SMEs different 54 problems was identified, in these pools of problems 28 are marketing related problems and 26 are non-marketing related problems. These 28 problems are categorized in five categories. First category denotes the poor relationship with customers, intermediaries and to access raw materials, quality accreditation, paten right, training assistance, media, financial institutions, research institutes and higher educations. Second category contains, poor innovation in products, pricing system, promotion system and distribution. Third category is the poor competitive advantage activities in product, prices, promotions and distribution. Forth category of problem explains inadequate and poor quality raw materials, raw material and output storage transportation problems and inappropriate outlets. Last category is the poor green marketing concern. Hence it is clear that SMEs in Northern Provinces have been facing complex environment and the struggling to grow up their performance [7]. At the same time SMEs have plentiful opportunities in the Northern Province [12]. There is needed to take a more targeted approach to reinvigorating the north. Application of blend of marketing strategies better deal with these problems in post war and risk in frontier market and enjoy superior performance and development in SMEs.

\section{Significance of Study}

Day et al., [13] conceive marketing strategy as marketing decisions and activities related to generating and sustaining competitive advantage. This marketing strategic conception ascertains some utility to SMEs in post war markets. Jeanine and Harmeling [14] described that understanding the marketing strategies is critical for the success, development and long term survival of organizations. This Marketing strategy concept proposes a roadmap to be followed to overcome their marketing problems by SMEs for successful marketing practice. This research, being the first of its kind, investigates the marketing strategies in SMEs in post war market situations. It also shows that new dimensions of marketing strategies to manage the risk of post war market variably influence in development of SMEs. Hence, this study and its findings can significantly contribute to the literature relating to marketing strategy towards the development of SMEs in the post war market. Further this study has attempted to identify both market strategy based on the problems and risk of SMEs and its components as relationship marketing strategy, competitive marketing strategy, diversification and green marketing strategy by using the literature and research models. In addition this research identifies the essential development factors in SMEs as financial, customer, employees and social perspectives. Finally this study has articulated passionate the new trend of theory to SMEs in this dynamic, competitive and ecological consideration in this world.

\section{Marketing Strategy}

Marketing strategy is a broad principles and marketing logic by which business units achieve its marketing objectives $[1,15]$. Ansoff [16] revealed corporate strategy-growth strategies as penetration, product development, market development and diversification. Porter [17-19] designed corporate strategy as cost leadership, differentiation and focus strategies. Borden [20] suggested marketing mix strategies, and then McCarthy [3] drafted the effective Marketing Mix as the first mix checklist (12 Section, two dozen subsections). McCarthy [3] created 4 Ps marketing mix strategies. Skimming and penetration as pricing strategy was deliberated by Dean [21]. Marketing strategies mostly consider the competitive forces, Alderson [22,23] presented competitive strategies for differential advantages.

Stanton et al., [24] examined the development of marketing strategies in the Australian electricity distribution market to overcome the competitions as cost leadership, differentiation, and focus strategies. Lado et al., [25] developed a marketing model as product-based, price-based, promotion-based, and distribution-based strategies that explained the export sales volume by destination based on a company's export marketing strategy with six different regional markets made by exporting companies in a southern European country. Bang and Joshi [26] identified market expansion strategy in Asian countries like India and China. Tang and Hull [27] investigated that how Chinese SMEs configure marketing, cost-control, and innovation strategies in order to attain better organizational effectiveness and put forward three strategies; marketing-oriented strategy configuration, cost-controlling oriented strategy configuration and innovativeness-oriented strategy configuration. Yang et al., [28] exposed environmental marketing strategy effects on market-based assets listed firms in China. Basu [29] revealed product market strategies and innovation types: finding the fit covered multidivisional and multinational corporations; these strategies were market penetration-incremental innovation, product development-modular innovation, market development- architectural innovation and diversification-radical innovation.

\section{Frame Work of Marketing Strategy for the SMEs in the Post War}

SMEs in Northern Province have been struggling from severe competition by local and international brands. Further these SMEs are situated in the problematic and challengeable postwar market. These marketing problems of pilot study are categorized under poor relationship, lack of innovation, poor competitive activities, inadequate related diversification and poor environmental consideration. SME in Sri Lanka contains high risk that is fluctuating performance and slow development. There is huge need to create a proper conceptual framework of marketing strategy to overcome the challenges in the post war market; it will help the management in its choice of marketing strategic decision for SMEs. Our proposed conceptual framework is based on the understanding of the post war market. Universally there is much kind of marketing strategies, but applicability of strategic marketing planning process has come under scrutiny in the post war market. Hence instead of attempting to develop a common strategy for postwar markets, we propose a unique framework that provides useful strategy in this trend of competitive and dynamic environment for development.

Significant models were identified for marketing strategy from different context. They are green marketing strategy, effective marketing strategy [26], social network marketing strategy [30], relationship marketing strategy [31], product market strategy and innovation types, product life cycle based marketing strategy [32], sustainable marketing strategy, marketing strategy for SMEs [27], market expansion strategy [26], innovative marketing strategy, global marketing strategy, export marketing strategy [25], enviropreneurial marketing strategy, competitive marketing strategy [33] and product market strategy [16]. Empirically suggested and tested strategies for SMEs were green marketing strategy, strategy, competitive strategy, relationship marketing strategy, innovative marketing strategy, market oriented strategy, cost controlling oriented strategy.

Porter [19] revealed three dimensions of competitive strategy as differentiation, cost leadership and focus strategy. Yan and Chew 
[34] presented competitive strategies from differentiation in terms of product features, inimitable products, product customization, and superior customer service. At the same time, Julien and Ramangalahy [35] product quality and product innovations are suggested as differentiation features for competitive advantage. The product differentiation with cultural match is one of the major competitive factors for success of organizations. Clark [36] expressed about workable competition and strategies, and exposed the dynamic competitive strategies. Hunt and Morgan [37] put forward comparative advantage theory of competition, applications on products. Yan and Chew [34] explained how the cost leadership can be achieved with the low prices to low cost of production, low operating cost and latest technology application. Further mentioned the feature of high quality products with high prices under cost leadership. Julien and Ramangalahy [35] described advertisement approach to competitive advantage that focuses on media selection, dissemination of information, spread market knowledge and innovative design. Distribution networks, firms' locations, suitable timing and market development are the major features under the distribution which contributes for the competitive advantage. SMEs have been facing severe competition by local and foreign brands. SMEs want to consider and observe the competitors' applications on advertisements and distributions, then initiate or imitate the competitive strategies to capture the market. Competitive advantage can be achieved through cost leadership or differentiation [38]. Golob and Podnar [39] described how it is possible to gain a competitive advantage through differentiation in product in European Union (EU) firms. With the above theories and researches, this study advocates that all micro, small and medium enterprises are essential to apply differentiation, cost leadership, focus, advertising and distribution marketing strategy for their success and survival.

Relationship marketing strategies are interactive marketing strategies supported by Guanxi, alliance and customer response capability $[34,40]$. Having relationship with customers, whole sellers, retailers, and all other related organizations and persons are the key factor for success and create positive image for organization nowadays [40]. Gronroos [41] suggested that organization has been designed the relationship marketing strategy based on customer relationship which includes identification of the needs and wants of customers and their changing expectations. Payne et al., [42] also suggested the essential model of relationship marketing strategy to organization success and survival. Relationship marketing builds strong economic, technical and social ties among the parties [4]. Madhavaram et al., [31] suggested that inter firm partnerships, repeated business contacts, relationship with competitors and non-profit organizations and sharing knowledge from one organization to another are expected alliance competence in organizations. Yan and Chew [34] suggested the customer response capability under relationship marketing, they are interaction orientation, customer response expertise and customer response speed. Having literature and research models, we proposed the relationship marketing strategic application for SMEs in Northern Province. This can be accomplished by inducing the SMEs to be uniqueness and differentiated marketing activities at the same time high quality marketing mix features adaptations. Haluk at al., [43] discussed that customer profile and data warehouse information about all stakeholders of organization are bases for promotion and distribution decision. Ballantyne [44] emphasized that a relationship marketing strategy is effective strategy for SMEs and large segment of the market.

Another strategic focus is social network marketing strategies. Matzler et al., [45] put forward the innovation model and organization success depends on an innovative marketing strategies and coherent designs of business models. Vásquez and Escamilla [30] designed social marketing strategy in successful interaction between stakeholders and institutions. Swami and Porwal [46] explained the dimensions of social marketing as the deliver real time information, co-created publicity, power to influence and customer feedback which link with the entrepreneurship success. Hsu explained that Taiwanese Organizations easily deal with global competitions when they adopt social marketing strategic model. Tsimonis and Dimitriadis [47] developed a conceptual analysis of social strategic marketing, and examined their contribution for the success of an organization, and provide value to the customer. The innovative social marketing strategy is recommended to micro, small and medium enterprises in Northern Provinc.

Another marketing strategy is related diversification. Small and medium enterprises are successful and they try to expand their market into national, international and global with some structural changes. Ansoff [16] suggested the diversification can be related or unrelated of business; the related diversification includes the backward integration and forward integration. Powerful firms wants to strength operations, and flow of materials, uninterrupted circulation of products and quality and prompt work by adopting backward and forward integration [48]. Diversified business groups have become active players in Chinese economy in the recent years [48]. This diversification strategy is proposed to the small and medium enterprises in Northern Province.

McDaniel and Rylander [49] argued that "Green Marketing" is taking shape as one of the key business strategies of the future, and that the increasing environmental consciousness makes it incumbent on consumer marketers not just to respond to it, but to lead the way in environmental programs. Devi et al., [50] analysed regarding various hypermarkets and supermarkets in Mauritius and found out the possibility of introducing greener patterns of consumption into contemporary lifestyles in the current context where green products are increasingly available. The most consumers have expressed a great interest in the protection of the environment and they are strongly concerned about the environment and its degradation. Devi et al., [50] indicated an overall positive correlation between effective green marketing strategies and customers' purchasing patterns for green products. LeCren and Ozanne [51] presented green purchasing, green packaging and waste disposal and green supply chain marketing strategies in organizations. Further they provided guidance for marketing and management leaders in organizations to gain a greater understanding of the consequences associated with green strategies. Managers need awareness of the potential impacts of choosing a green orientation and strategy [52]. Dean and Pacheco [21] described that green marketing strategy represent promising opportunities for value creation and market growth. In the case of developing countries, environmental considerations are very poor in SMEs. Newly establishing firms in NP are instructed and ruled to follow the environmental regulations. Already established organizations are not restricted to follow the environmental rules. But it very important to concern, protect and balance the environment. This strategy is very strictly recommended to small and medium enterprises in Northern Province.

Having flowed the problems of SMEs in post war, risk in frontier market, literature and strategic models, dissected marketing strategy has developed this marketing strategic framework is shown in Figure 1. Based on the problems identified in pilot study on SMEs: Poor relationship, lack of innovation, poor competitive activities, inadequate related diversification, poor environmental consideration, 


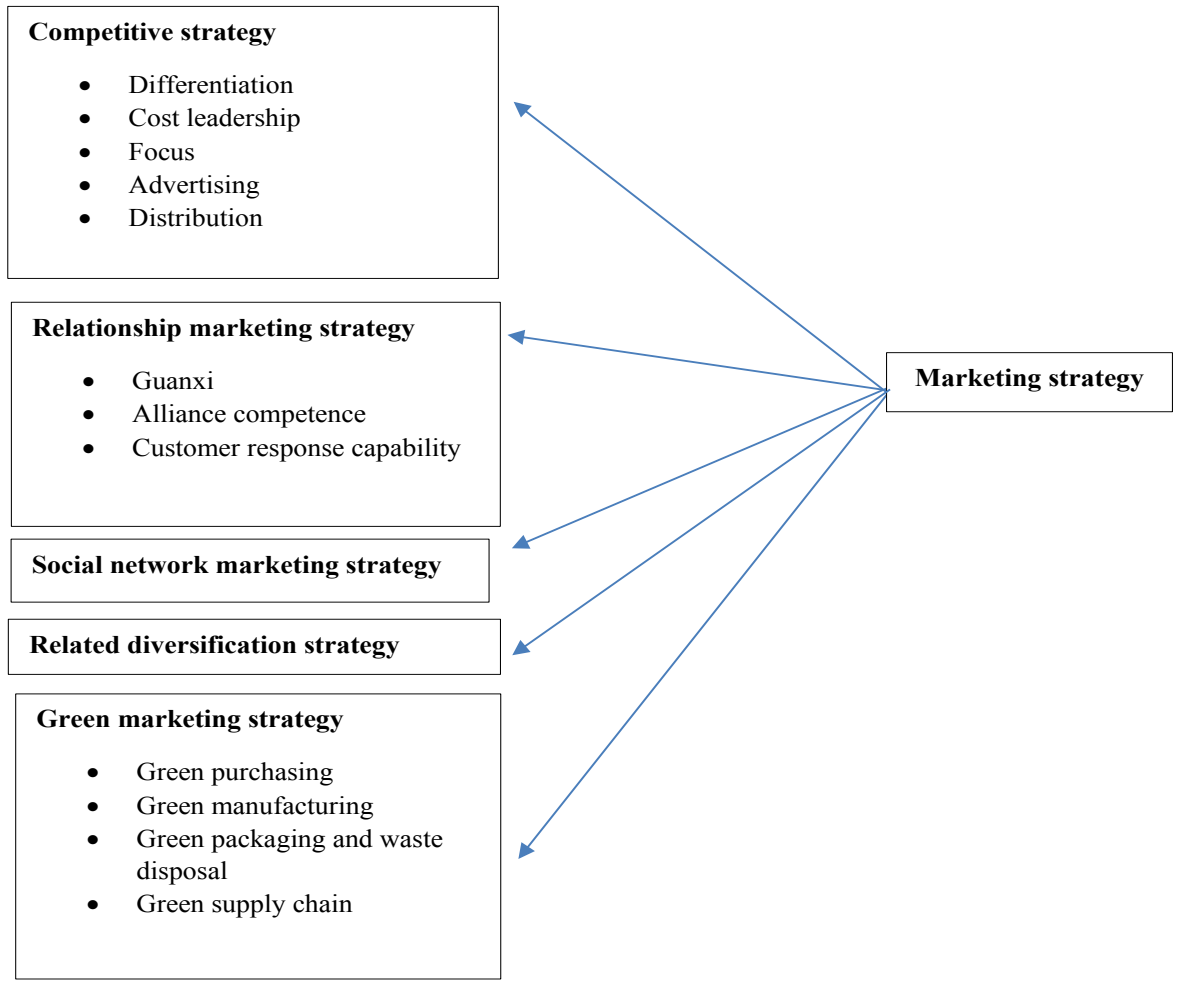

Figure 1: Post war marketing strategies of SMEs.

risk of frontier market, new marketing strategic framework were produced. The five major marketing strategies are competitive strategy, relationship marketing strategy, social marketing strategy, related diversification and green marketing strategy.

\section{Frame Work of Development of SMES in the Post War Market}

Development is the process in which someone or something grows or changes and becomes more advanced and gradual growth of something in organization. Ellerby and Taylor [53] stated that organization development is aimed at improving organizational effectiveness. Development can be related with organizations. Organizational development defined as a planned intervention of change for group, team or organization to improve organization. Further organization development is an approach to change in growth, enhancing human skills and resolving difficulties at both the personal and organizational levels and it is developing successful, productive organization what supplements are to the serious body builder. Indicators of SME's development are also described as outcome based as the success of SMEs, the performance, investment over five years and number of markets. According to Bennett and Brodie [54] indicator of development is the role a manager takes on performance and effectiveness and success of SMEs. Tulus Tahi Hamonangan Tambunan [55] discussed the development of SMEs with the special focus on the four issues; they are the role of SMEs, critical constraints, development of women entrepreneurs in SMEs and innovation capability. Researcher focus on the identification of the most relevant tendencies in the SMEs sector from the perspective of six indicators considered to be relevant: the number of enterprises, the number of persons employed, the gross value added, the apparent labor productivity, the rate of profitability and the propensity to invest.
Based on semantic earlier theories and models of development were considered for the development of conceptual model in this research. Among many dimension of development, financial perspective, customer perspective, people (employee) perspective, growth perspective and social perspectives were considered as major elements for this research. Financial perspective encourages to high-level financial performance as cash flow, total revenue, return on equity, and return on assets, leverage ratio and liquidity ratio. Financial perspective is the major development factor of sustainable development of SME. Customer perspective encourages the identification of measures important to our customers as number of new customers, product return rate, and customer retention rate, on time delivery, share of important customer purchases, customer satisfaction and ranking by important customers. Employees' development was foundation for organization development which includes sustainable job and benefit, worker development, innovation and training and leadership. Sustainable jobs and benefits is to concentrate on getting people into work, sustain them and allow to increase their hours and pay to a point where they no longer need the state to top up their earnings and moving people into sustainable work, improve lives and the benefit. Worker development emphasis on teamwork and group activities, employee involvement, learning, quality of work life, human resource capacity utilization and productivity. Innovation and training of employees leads to developing multi-skilled and new method production worker, develop knowledge and skills by initial and continuous training and continuous improvement in training. Leadership includes employee care, equal and fair treatment, building the confidence and information to employees. Growth of organization was indicated by the development of number of branches or sales centres, increased information transfer speed, number of employees, turnover and capital growth, new product introductions, advances in technical, financial, marketing and other field of competence; develop new generation of products and the 
mentality to face risk. Social perspectives is related to benefits for the community, sell products related to the natural, historical and cultural environment, involvement in the community's ecological projects, contribution to the local infrastructure development, education for the community and reducing risk to human health and safety (Figure 2).

Based on semantic earlier theories and models of development were considered for this research. Among many dimension of development, financial development, customer development, people (employee) development, growth of enterprise, internal process development, learning and development and social development were considered as major elements for this research. Under employee development, sustainable job and benefit, human resource development, worker development, innovation and training, knowledge and learning and leadership were considered.

\section{Frame Work of Marketing Strategy and Development of SMEs in the Post War Market}

Conceptual model regarding marketing strategy is constructed to assess the development of SMEs. In this stance, this study centers the SMEs in Northern Province of Sri Lanka, which was highly war affected province. Previous theories, models and approaches on the subject of relationship marketing, competitive marketing, social network marketing strategy and green marketing are used, which [37] which is considered for limited resource of SMEs and stakeholder theory which is considered to satisfy not only shareholder and customer but also all essential related people for SMEs, are used as the main underpinning theories to construct this model as an integrated one to predict the marketing strategy in a strong way. Based on semantic earlier theories and models of development were considered for this research. Among many dimension of development, financial development, customer development, people (employee) development, growth of enterprise and social development were considered as major elements for this research.

Most valuable variables of marketing strategy as relationship marketing strategy [31], competitive strategy [33], social network marketing strategy [30], related diversification [16] and green marketing strategies are identified through the literature and empirical models. The variable for development as financial perspectives, customer perspectives, people (employee) perspectives, growth perspectives and social perspectives were identified form empirical studies and models. The link between the marketing strategy and development was diagnosed form the earlier empirical studies [26-28]. To this end, model constructed for this study is distinctive; it is based on established theories and models in the line of SMEs and postwar market. Further it provides a well-supported explanation for marketing strategy and development model for SMEs (Figure 3).

Relationship marketing strategy is essential for the survival of the organization [56] Social, competitive and diversified marketing applications are required to compete the organizations with the international trends $[39,46,48]$. Green environmental consideration is prominent for the organizations for a long time success and wellbeing of society [50]. There is lack of researches on marketing strategies of SMEs in Sri Lanka, particularly no one researches produced marketing strategies for SMEs in postwar market.

\section{Conclusion}

This study has suggested five major strategies; competitive marketing strategy, relationship marketing strategy, social network market-

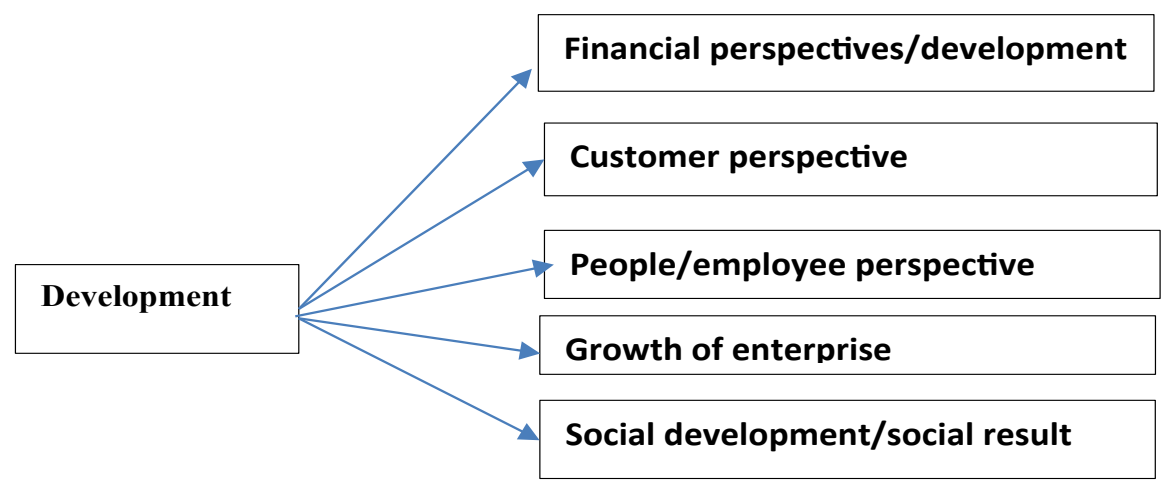

Figure 2: Development of SME in post war market.

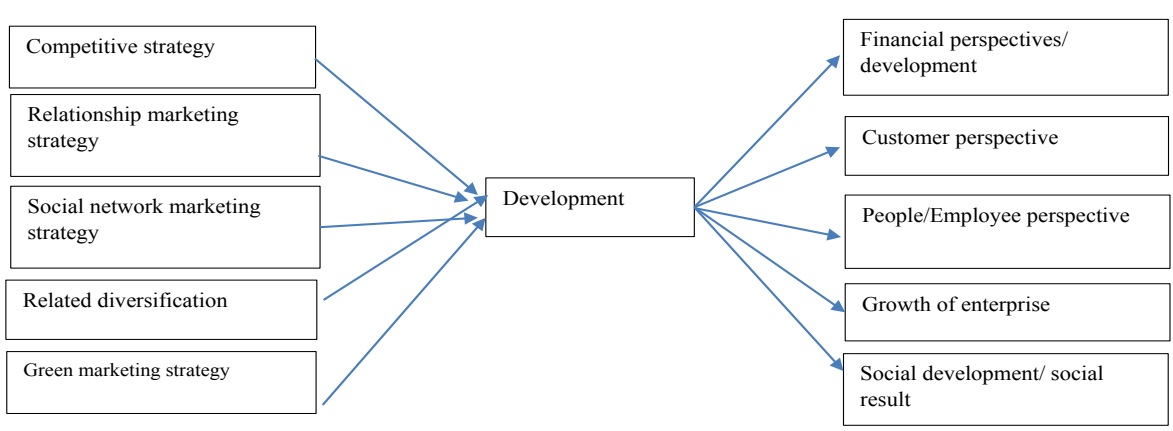

Figure 3: Model of marketing strategy and development of SMEs in the postwar market. 
ing strategy, related diversification and green marketing strategy, for development of SMEs in the postwar frontier market, these strategies are also roadmap to foothold the nation towards the emerging market. Total quality movement drive among the companies has led to the enhancement of relationship marketing. Relationship marketing attempts to involve and integrate customers, suppliers and other infrastructural partners into a firm's developmental and marketing activities. Sophisticated technology application like computers and telecommunications that allow the producers to interact with the customers. In addition this study investigates the competitive marketing strategy and its findings can potentially be applied to take competitive advantage of SMEs. Fundamental problems of SMEs are to compete with the local, national and international brands. The proposed conceptual frame work offers unique path to competitive advantage in post war market. This study suggested social network marketing strategy in the SMEs. Firms can employ these marketing strategies to disseminate the information to customers and all other stakeholders to deal with global competition. This innovation social network marketing strategy comprises a unique, innovative and coherent design of the strategic marketing model's components for the SMEs. Many micro producers are getting involved in productions by raw material availability from their own places. Many producers sell their products directly to customers; these are major related diversification features of SMEs. Diversification also drives high performance in medium enterprises. Finally, green environment is very needful application to small and medium enterprises to enhance their social considerations. Environmental marketing can represent promising opportunities for value creation and market growth. Most of the SMEs are in introduction and growth stage of product life cycle. In these stages more expenses for their growth and development. They earn low level financial outcomes, at the same time the other developments are undertaking. That's why researcher focused not only the financial outcomes but also the other dimensions; customer, people, growth and social development. Researcher has produced a novelty model with a broad idea as development rather than performance only, which was linked with the marketing strategy in this research.

\section{References}

1. Kotler P, Armstrong G, Saunders J, Wong V (1999) Priciples of Marketing (Second European Edition ed.). Upper Sadle River: Prentice Hall Inc.

2. Robinson $\mathrm{J}$ (1933) The economics of imperfect competition. MacMillan and Company, London.

3. McCarthy EJ (1960) Basic marketing: A managerial approach. Homewood, IL: Richard D. Irwin. Inc.

4. Kotler P, Keller KL (2009) Marketing direction. Pearson Education.

5. ESBA (2011) Micro and small Business in the EU. European Small Business Alliance.

6. Lazer W, Culley JD (1983) Marketing management: Foundations and practices. Houghton Mifflin Company.

7. NHREP (2012) Small and Medium Enterprises (SME).

8. Economic Census (2014) Department of Census and Statistics Ministry of Policy Planning Economic Affairs, Child Youth and Cultural Affairs.

9. Ministry of Industry and Commerce (2015) National Policy Framework for SME Development.

10. FTSE Russell (2014) FTSE Global Equity Index Series Country Classification.

11. Fernando S, Bandara JS, Smith C (2013) Regaining missed opportunities: The role of tourism in post-war development in Sri Lanka. Asia Pacific J Tourism Res 18: 685-711.

12. Gamage AS (2003) Small and medium enterprise development in Sri Lanka: A review. Meijo University, Faculty of Business Management, Nagoya, Japan.

13. Day GS, Weitz BA, Wensley R (1990) The interface of marketing and strategy 4.
14. Jeanine Meyers $Y$, Harmeling SS (2011) Best address: The use of innovative marketing in the real estate industry. Journal of Research in Marketing and Entrepreneurship 13: 74-84.

15. Kotler $P$ (1999) Marketing management: Millennium edition. $10^{\text {th }}$ edition Prentice Hall, India.

16. Ansoff HI (1957) Strategies for diversification. Harvard Bus Rev 25: 113-124.

17. Porter ME (1980) Competitive strategy: Techniques for analyzing industries and competitors. Free Press, New York.

18. Porter ME (1985) Competitive advantage: Creating and sustaining competitive advantage. Free Press, New York.

19. Porter ME (1990) The competitive advantage of nations. Free Press, New York

20. Borden NH (1964) The concept of the marketing mix. J Advert Res 4: 2-7.

21. Dean J (1951) Managerial Economics. Prentice Hall, Englewood Cliffs, N J.

22. Alderson W (1937) A marketing view of competition. JJ Mark 1: 3.

23. Alderson W (1957) Marketing behavior and executive action. Richard D. Irwin Homewood, IL.

24. Stanton PJ, Cummings S, Molesworth J, Sewell T (2001) Marketing strategies of Australian electricity distributors in an opening market. Journal of Business and Industrial Marketing 16: 81-93.

25. Lado N, Martínez-Ros E, Valenzuela A (2004) Identifying successful marketing strategies by export regional destination. Int Market Rev 21: 573-597.

26. Bang VV, Joshi SL, Singh MC (2015) Market up-gradation strategies, volume expansion strategy, market expansion strategy, demand fulfilment strategy.

27. Tang Z, Hull CE (2011) The strategy configuration of Chinese SMEs. J Enterprising Culture 19: 229-259.

28. Yang D, Zhao $P$, Lou R, Wei $H$ (2013) Environmental marketing strategy effects on market-based assets. Total Quality Management and Business Excellence 24: 707-718.

29. Basu S (2014) Product market strategies and innovation types: Finding the fit Strategic Direction 30: 28-31.

30. Vásquez GA, Escamilla EM (2014) Best practice in the use of social networks marketing strategy as in SMEs. Procedia Soc Behav Sci 148: 533-542.

31. Madhavaram S, Granot E, Badrinarayanan V (2014) Relationship marketing strategy: an operant resource perspective. J Business and Industrial Marketing 29: $275-283$.

32. Shaw EH (2012) Marketing strategy: From the origin of the concept to the development of a conceptual framework. J Historical Research in Marketing 4 : 30-55

33. Porter ME (1979) How competitive forces shape strategy. Strategic Planning Readings, pp: 102-117.

34. Yan S, Chew DA (2011) An investigation of marketing strategy, business environment and performance of construction SMEs in China. Afr $\mathrm{J}$ Bus Manage 5: 2396-2405

35. Julien PA, Ramangalahy C (2003) Competitive strategy and performance of exporting SMEs: An empirical investigation of the impact of their export information search and competencies. Entrepreneurship Theory and Practice 27: $227-245$.

36. Clark JM (1961) Competition as a dynamic process.

37. Hunt SD, Morgan RM (1995) The comparative advantage theory of competition. J Mark, pp: $1-5$.

38. Davies M (1992) Sales promotions as a competitive strategy. Management Decision 30.

39. Golob U, Podnar K (2007) Competitive advantage in the marketing of products within the enlarged European Union. Eur J Mark 41: 245-256.

40. Wilson NC, Stokes D (2004) Laments and serenades: relationship marketing and legitimation strategies for the cultural entrepreneur. Qualitative Marke Research: An Inter J 7: 218-227.

41. Grönroos C (1994) From marketing mix to relationship marketing: Towards paradigm shift in marketing. Management Decision 32: 4-20. 
Citation: Sathana V, Velnampy T, Rajumesh S (2018) A Conceptual Study of Marketing Strategy and Development of SME. J Account Mark 7: 282. doi: 10.4172/2168-9601.1000282

Page 7 of 7

42. Payne A, Ballantyne D, Christopher M (2005) A stakeholder approach to relationship marketing strategy: The development and use of the "six markets" model. Eur J Mark 39: 855-871.

43. Haluk Köksal M, Özgül E (2007) The relationship between marketing strategies and performance in an economic crisis. Marketing Intelligence and Planning 25: $326-342$

44. Ballantyne D (2000) Internal relationship marketing: A strategy for knowledge renewal. Inter J Bank Marketing 18: 274-286.

45. Matzler K, Bailom F, Friedrich von den Eichen S, Kohler T (2013) Business model innovation: Coffee triumphs for Nespresso. J Bus Strategy 34: 30-37.

46. Swami S, Porwal RK (2005) Entrepreneurship, innovation and marketing: Conceptualization of critical linkages. J Advances in Management Res 2: 54-69.

47. Tsimonis G, Dimitriadis S (2014) Brand strategies in social media. Marketing Intelligence and Planning 32: 328-344.

48. Zhao J (2010) Ownership structure and corporate diversification strategies of Chinese business groups. Management Research Review 33: 1101-1112.

49. McDaniel SW, Rylander DH (1993) Strategic green marketing. J Consumer Marketing 10: 4-10.
50. Devi Juwaheer T, Pudaruth S, Monique Emmanuelle Noyaux M (2012) Analysing the impact of green marketing strategies on consumer purchasing patterns in Mauritius. World Journal of Entrepreneurship, Management and Sustainable Development 8: 36-59.

51. LeCren N, Ozanne LK (2011) Consequences of corporate environmental marketing strategies in New Zealand organisations. Marketing Intelligence and Planning 29: 156-177.

52. Dean JT, Pacheco D F (2014) Green marketing: a strategic balancing act for creating value. J Bus Strategy 35: 14-22.

53. Ellerby N, Taylor B (2005) Organisational development, the oasis approach: A human relations perspective.

54. Bennett R, Brodie M (1979) A perspective on managerial effectiveness. pp 12-31.

55. Tahi Hamonangan Tambunan T (2011) Development of small and medium enterprises in a developing country: The Indonesian case. J Enterprising Communities: People and Places in the Global Economy 5: 68-82.

56. Parasnis G (2012) From social media to social CRM: What customers want. 